\title{
ACÉLSZERKEZETEK RIDEGTÖRÉSSEL SZEMBENI BIZTONSÁGA
}

\section{STEEL CONSTRUCTIONS SAFETY AGAIN COLD CRACKING}

\author{
Kovács-Coskun Tünde \\ Óbudai Egyetem, Bánki Donát Gépész és Biztonságtechnikai Mérnöki Kar, Tan- \\ szék), Cím: 1081, Magyarország, Budapest, Népszínház, 8; Tel/Fax:+36-1-6665327, \\ kovacs.tunde@bgk.un
}

\begin{abstract}
The behaviour of the materials depends not only on the chemical composition and microstructure. Usually it depend also on the temperature, notch and shaping rate too. In case of welded joint we have to take account of the material properties and also the effect of welding technology.
\end{abstract}

Keywords: Charpy impact test, cracking, cold cracking, notch.

\section{Összefoglalás}

Az anyagok szívós rideg viselkedése nem csupán a kémiai összetétel és a szerkezet függvénye. Gyakran küldő állapothatározók is befolyásolják a repedésképződési folyamatot. A hegesztett szerkezetek esetében pedig még az anyag jellemzőin kívül figyelembe kell venni a technológia hatását is.

Kulcsszavak: Charpy vizsgálat, repedés, hidegtörés, bemetszés.

\section{Bevezetés}

Mindenki által ismert katasztrófák, mint a Titanic vagy a Liberty hajók és számos acélszerkezet tönkremenetelét okozta ridegtörés. Ebben a dolgozatban áttekintést kívánok adni a ridegtörés okairól illetve elkerülési lehetőségéről, mind az anyagválasztás mind a szerkezettervezés oldaláról. Továbbá a teljesség igénye nélkül vizsgálni kezdem az acélok mikroszerkezetének ridegtörési hajlamra gyakorolt hatását és az egyes szövetszerkezetek valamint a fázisátalakulások kialakulását okozó hatásokat.

Végül pedig arra teszek kísérletet, hogy a szerkezetek biztonságos üzemelése érdekében betartandó szabályokat és technológiai követelményeket igyekszem összefoglalni.

\section{Ridegtörés jelensége és okai}

\section{1. Állapothatározók}

A ridegtörési káreseményeket követően a kutatók megfigyelték, hogy minden esetben a laboratóriumi vizsgálatok során kapott szilárdsági és szívóssági tulajdonságok megfelelöek voltak. A szerkezetek a megengedett terhelés alatti igénybevétel mellett mutattak ridegtöréses tönkremenetelt. Ridegtörésnek azt a töréssel bekövetkező káreseményt tekintjük, amikor a szerkezet képlékeny alakváltozás nélkül, nagy sebességgel szenvedi el a törést [1].

A megfigyelések azt mutatták, hogy nem az anyag kémiai összetétele felel ezekért az esetekért, hanem külső hatások, melyeket állapothatározóknak nevezünk. 


\subsubsection{Hőmérséklet}

A káreseteknél megfigyelték, hogy a törés a laboratóriumi hőmérséklet $\left(20^{\circ} \mathrm{C}\right)$ alatt következett be. Charpy kísérletei során a hőmérséklet hatását vizsgálta és kimutatta, hogy acélanyagok esetében a hőmérsékletváltozás hatására megváltozik a szívós rideg törési mód. Alacsonyabb hőmérsékleten ridegebb viselkedés figyelhető meg. A törési munka segítségével meghatározható az átmeneti hőmérséklet (TTKV) mely a szívós rideg viselkedés határát mutatja $\left({ }^{\circ} \mathrm{C}\right)$. Az átmeneti hőmérséklet felett az adott acél szívósan alatta ridegen viselkedik.

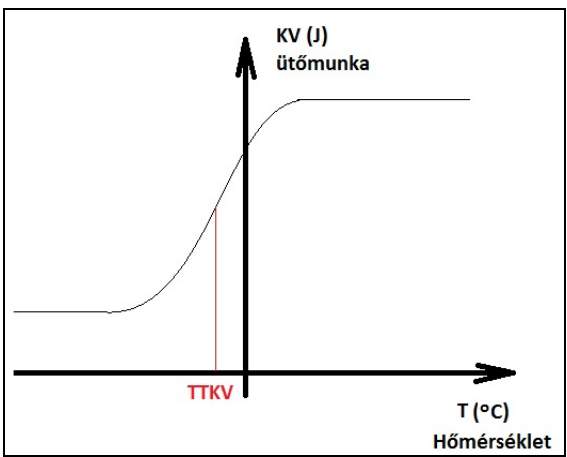

1. ábra. Charpy ütömunka diagram, átmeneti hömérséklet (TTKV)

Az átmeneti hőmérséklet felett az adott acél szívósan alatta ridegen viselkedik.

\subsubsection{Feszültségállapot}

A gépészeti gyakorlatban szállóigévé vált ,éles sarok kezdő törés” arra utal, hogy a többtengelyü húzófeszültség szintén a ridegtörésnek kedvez. Ezért a szerkezettervezés során külön figyelmet kell fordítani a szerkezet geometriájának, vagyis pl. tengelyek esetében a lekerekítéseknek, hegesztett szerkezeteknél pedig a varratkereszteződések elkerülésének.

\subsubsection{Alakítási sebesség}

A káresetek tanulmányozása során az alakítási sebesség hatását is kimutatták. A szakító vizsgálat elvégzésénél alkalmazott húzó sebesség például nem választható szabadon, mivel ez befolyásolná a kapott eredményt. A hidegalakítási megmunkálások esetében is lényeges a megfelelö alakítási sebesség, hiszen túl nagy sebességü alakítás a munkadarab rideg viselkedését okozná, ezzel selejtes darabok készülnének.

\section{Ridegtöréssel szembeni bizton- ság}

A szerkezetek tervezése során, tehát elsődleges, hogy azokat a hatásokat figyelembe vegyük, melyek a ridegtörési hajlamot segítik.

\subsection{Anyagválasztás}

A hegesztett szerkezet tervezése során az alapanyagot a mechanikai igénybevételekre és az üzemi hőmérsékletre méretezve kell elvégezni. Acélminőségek tekintetében ez azt jelenti, hogy az alacsony hőmérsékeltű alkalmazásokhoz megfelelő ütőmunkával rendelkező alapanyagot kell elöírni a mechanikai tulajdonságok megfelelősége mellett.

\subsection{Szerkezet tervezése}

A szerkezet tervezése során igen fontos, hogy a varratkereszteződéseket (2. ábra), a feszültséggyüjtő helyeket elkerüljük. A varratok kezdete és vége is jelenthet veszélyforrást, ha azok kritikus igénybevételnek vannak kitéve.

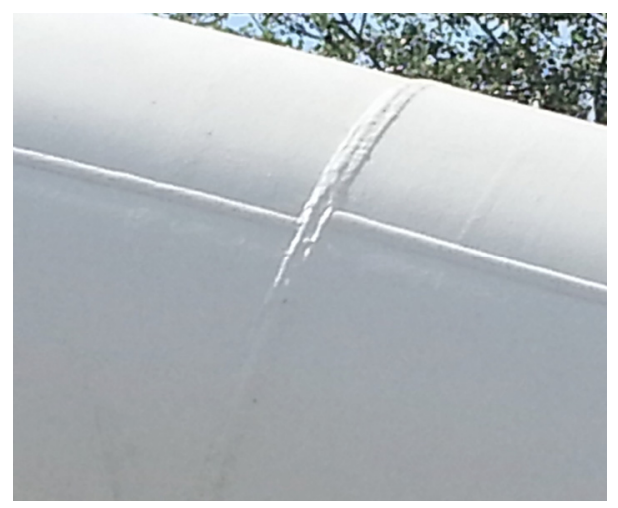

2. ábra. Szolnoki híd varratkeresztezödés 


\subsection{Mikroszerkezet}

Az anyagok tulajdonságait a kémiai öszszetételük és a szövetszerkezetük határozza meg. A terhelések elviselésére megfelelően kiválasztott anyag azonban a szerkezetépítési technológia hatására megváltoztathatja mikroszerkezetét és bizonyos esetekben akár kémiai összetételét is.

Például a magas hőmérsékleten üzemelő acélok esetében különböző kémiai folyamatok hatására létrejövő dekarbonizáció vagy éppen cementálódás esetleg oxidáció, stb következhet be. Ezek a folyamatok az anyag kémiai összetételének megváltozását okozva változtatják meg a mechanikai tulajdonságokat is.

A mikroszerkezetet megváltoztathatja pl. a képlékeny hidegalakítás (alakítási martenzit), a hegesztés során bevitt hő hatása (szemcsedurvulás, kiválások, martenzites átalakulás, stb.) vagy a radioaktív sugárzás mely a kristályrácsban okozhat változást.

Mikroszerkezet változását okozhatja a hegesztett szerkezet esetén a bevitt hö és az ezt követö gyors hülés.

A folyamatos hütési diagramon (3. ábra) a hütési sebesség hatása látszik egy adott alapanyag esetében.

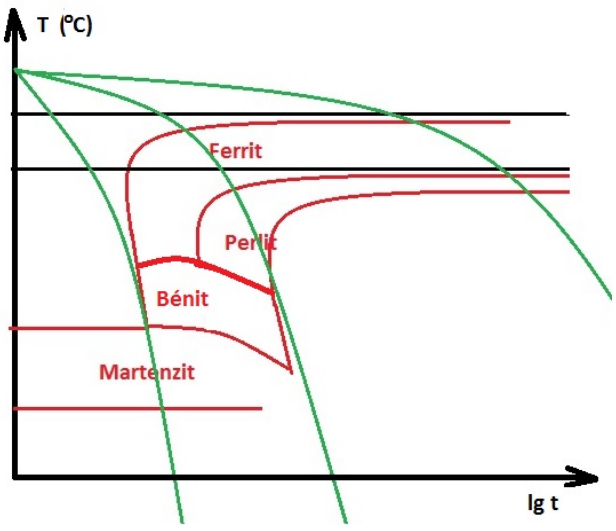

3. ábra. Folyamatos hütési diagram ötvözetlen hipoeutektoidos acélra
Túl gyors hülés a höhatásövezetben martenzites átalakulást okozhat, mely rideg, képlékenységet nem mutat, így repedés és törés kiinduló pontja lehet. A gyors hülést okozhatja a hegesztett szerkezet falvastagsága miatti jelentős hőelvonás vagy az ötvözők hatása miatti akár lassabb hülés esetén bekövetkező beedződés.

\section{A mikroszerkezet átalakulásá- nak elkerülése}

A mikroszerkezet átalakulásának elkerülésére több módszer ismert a hegesztett szerkezetek esetében. Az előmelegítéssel a varrat és a hőhatásövezet hülési sebességét tudjuk mérsékelni. Valamint a szénegyenérték meghatározása is elengedhetetlen, ebből lehet következtetni, a rideg szövetelem megjelenésének valószínüségére.

Széleskörben ismert szénegyenérték összefüggés az alacsony ötvözöttségü acélokra [1]:

$$
C E_{\text {Breadstrea }}=\boldsymbol{C}+\frac{\boldsymbol{M n}}{20}+\frac{\boldsymbol{N i}}{15}+\frac{\boldsymbol{C r}+\mathbf{M o}+\boldsymbol{V}}{10}
$$

Azonban jelenleg a különböző acélcsoportok esetében ajánlott összefüggések száma meghaladja a 40-et.

Hogy melyik összefüggés kerül alkalmazásra azt a tervező dönti el. Ezekből az összefüggésekből a hegesztési technológia egyik fontos paraméterét határozhatjuk meg, az előmelegítési hőmérsékletet. Sok esetben tapasztalati úton adnak meg elömelegítési hőmérsékletet, mely nem biztos, hogy optimális.

Emellett nem elegendő csupán a szénegyenérték meghatározása, hiszen az elömelegítési hőmérséklet meghatározása ennél sokkal komplexebb feladat.

\subsection{Séférian módszer az előmelegítési hőmérséklet meghatározására}

Jól alkalmazható a Séférian féle összefüggés és diagram az előmelegítési hőmérséklet meghatározására. 
Séférian szénegyenérték [1]:

$$
C E_{\text {Séférian }}=\boldsymbol{C}+\frac{\boldsymbol{M n}+\boldsymbol{C r}}{9}+\frac{\boldsymbol{N i}}{18}+\frac{7 \boldsymbol{M o}}{90}
$$

Falvastagsággal korrigált összefüggés:

$$
\mathrm{CeC}=\mathrm{Ce}(1+0,005 \mathrm{e})
$$

Előmelegítési hőmérséklet Séférian szerint:

$$
\mathrm{Te}=350 \sqrt{\mathrm{CeC}-0,25}
$$

$\mathrm{Az}$ előmelegítési hőmérséklet meghatározható grafikus úton is az alábbi Séférian diagram alapján is.

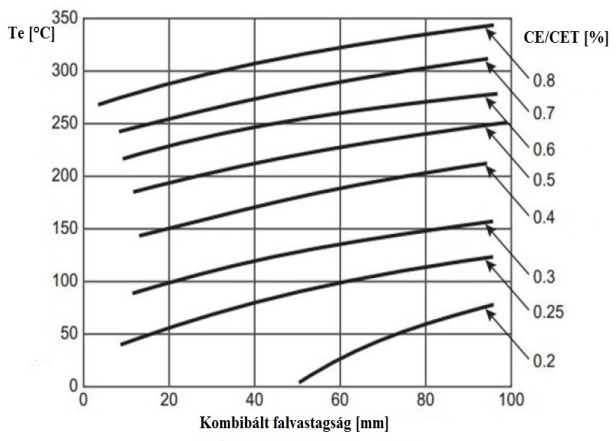

4. ábra. Séférian diagram az elömelegitési hömérséklet meghatározására [1]

\subsection{IIW módszer az előmelegítési hő- mérséklet meghatározására}

Az előmelegítési hőmérséklet meghatározásának egyik módszere kapcsolatot teremt a szénegyenérték (1) és az előmelegítési hőmérséklet között. Az egyik legelterjedtebb képletet az International Institute of Welding (IIW), azaz a Nemzetközi Hegesztési Intézet fogadta el 1968-ban [2]. Szénegyenérték, mely $0,05 \ldots 0,25 \%$ széntartalom között használatos:

$$
C E_{I I W}=C+\frac{M n}{6}+\frac{C r+M o+V}{5}+\frac{N i+C u}{15}
$$

$\mathrm{CE}=0,3 \ldots 0,7 \%$ tartományban érvényes. Ha $\mathrm{CE}$ értéke meghaladja a $0,45 \%$-ot előmele- gítés alkalmazása szükséges a hidegrepedés elkerülésére.

A másik képlet az MSZ1011-2 szerinti, Uwer-Höhne-től származó összefüggés (CET) alkalmazható $\mathrm{C}=0,05 \ldots 0,32 \%$ és magasabb ötvöző mennyiség mellett $(\mathrm{Mn}<1,9 \%, \mathrm{Cr}<1,5 \%)$.

$$
C E T=C+\frac{M n+M o}{10}+\frac{C r+C u}{20}+\frac{N i}{40}
$$

$\mathrm{CET}=0,2 \ldots 0,5 \%$ tartományban érvényes.

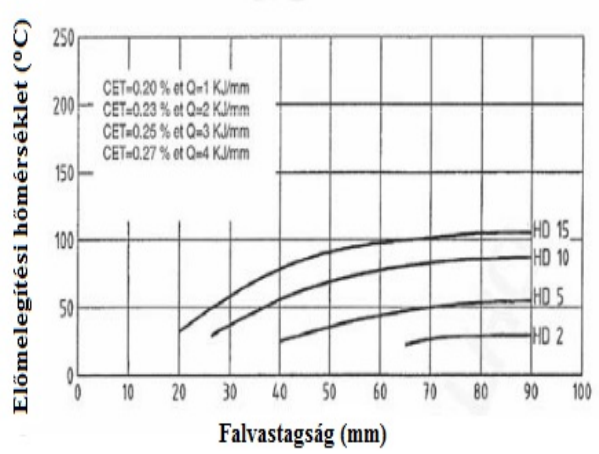

5. ábra. CET elömelegitési hömérséklet meghatározása [3]

\section{Következtetések}

Összefoglalva tehát elmondhatjuk, hogy a szerkezetek ridegtöréssel szembeni ellenállását akkor tudjuk garantálni, ha a tervezés és méretezés során figyelembe vesszük a ridegtörést okozó hatásokat.

\section{Szakirodalmi hivatkozások}

[1] M. Jean Claude TÊTOT: Métallurgie $d u$ soudage lère année BTS, Ministère de l'Éducation Nationale, de l'Enseignement Supérieur et de la Recherche,2011

[2] Dr. Szunyogh László: Hegesztés és rokon technológiák kézikönyv, Gépipari Tudományos Egysület 2007.

[3] Palotás B., Gyura L.: A hegesztési hőbevitel meghatározása ötvözetlen és gyengénötvözött acélok esetében a hidegrepedés elkerülésére, Hegesztéstechnika, III. évf. 4. szám (1992/4.) p. 13-17. 